Vol. 18, n² | 2014

Varia

\title{
Policing the empire / Policing the metropole : Some thoughts on models and types
}

\section{Clive Emsley}

\section{(2) OpenEdition \\ 1 Journals}

\section{Electronic version}

URL: http://journals.openedition.org/chs/1483

DOI: $10.4000 /$ chs. 1483

ISSN: 1663-4837

\section{Publisher}

Librairie Droz

\section{Printed version}

Date of publication: 1 October 2014

Number of pages: 5-25

ISBN: 978-2-600-01854-8

ISSN: 1422-0857

\section{Electronic reference}

Clive Emsley, "Policing the empire / Policing the metropole : Some thoughts on models and types ", Crime, Histoire \& Sociétés / Crime, History \& Societies [Online], Vol. 18, n² | 2014, Online since 01

October 2017, connection on 10 December 2020. URL : http://journals.openedition.org/chs/1483 ; DOI : https://doi.org/10.4000/chs.1483 


\title{
Policing the empire Policing the metropole:

\author{
Some thoughts on models and types
}

\author{
Clive Emsley
}

\begin{abstract}
Cet article examine les modèles et styles de police déployés par les puissances européennes dans leurs empires d'outre-mer. Il s'intéresse principalement aux forces de police créées dans l'Empire britannique et sur l'idée reçue que c'est la Royal Irish Constabulary qui leur a servi de modèle. L'auteur soutient qu'en réalité, les systèmes policiers de l'empire relevaient de combinaisons plus pragmatiques, en fonction de la taille et de la densité de la population européenne dans chaque colonie, des budgets disponibles, et de l'étendue et de la forme du territoire considéré. L'article s'appuie sur un précédent essai de typologie des polices européennes et suggère que cette version élargie fournit un point de départ à l'examen de la complexité des institutions policières coloniales, dont la pertinence dépasse le contexte impérial britannique.
\end{abstract}

This article discusses the models and styles of policing deployed by European powers in their overseas empires. The main focus is on the police forces created in the British Empire and the assumption that the model for these institutions was the Royal Irish Constabulary. The article argues that, in reality, police systems in the empire were much more of a pragmatic pick and mix depending on the size and spread of the European population in a colony, the finance available and the size and form of the region to be policed. It builds on an earlier typology of European police and suggests that this extended typology provides a starting point for exploring the complexities of colonial police institutions and that it has relevance beyond the British Imperial context.

$\mathrm{O}$ ver the last 40 years or so there has been an enormous growth in the history of policing. This began as an off-shoot of the study of the history of crime and popular disorder, partly as a way of exploring the way in which plebeian classes appeared to be subject to new forms of discipline, but partly also as a way of getting to grips with a working-class man (and before the early twentieth-century police officers were all male) in a particular form of work setting. Moreover, while the police officer could be criticised for being an instrument for imposing discipline on a new working class, it was also the case that police officers came from that working class and, in capital cities especially, could constitute one of the largest single labour

1 Clive Emsley is Emeritus Professor in the Department of History at the Open University. He would like to thank David Anderson, David Barrie, Mark Finnane and Georgina Sinclair for their comments and advice on earlier drafts of this article, as well as the three anonymous referees for this journal. He alone is responsible for any errors and inconsistencies. 
groups and one that developed a distinct organisational culture. The history of police in the European colonies during the nineteenth and twentieth centuries has been rather slower to develop, but important work is now beginning to appear. In this journal, for example, a recent cluster of essays addressed the topic beginning with an important conceptual study pointing out the hybrid nature of much colonial policing. This article stressed the professionalization of police practice as central to the colonisers' understanding of civilisation through public order maintenance. In the process the authors insist, rightly: "Les notions de "transfert" ou de "diffusion de modèles" policiers glissant des métropoles vers les colonies doivent en effet être abandonnées'. ${ }^{2}$ Yet, in the British case, particular models and styles of policing were often central to what colonial administrators declared that they needed, even if, when it came to making deployments on the ground, the police that they created and deployed often looked different from the model that they claimed to need.

Two final points by way of introduction. This article takes the contrast between English and Irish models as its starting point and its main focus is the British imperial experience. Two distinct models were, and in some quarters remain, central to the way in which the British imagined police. It is to be hoped, however, that the types described will have some relevance for imperial policing elsewhere, hence there are references to other colonial examples. Secondly, it seems sensible to include the United States among the colonial powers since much of the development of police institutions in the USA is reminiscent of that in Canada, of that in other white dominions of the British Empire, and also of that among many of the USA's southern, Hispanic neighbours.

\section{BRITISH MODELS AND A TYPOLOGY}

There is a commonly held view that there were two distinct models of British policing - the civilian model, originating in the Metropolitan Police of London and the imperial model inspired by the Royal Irish Constabulary and developed across the British Empire from the mid-nineteenth century. These models continue to be used, indeed it can be said that they are currently 'marketed' in the contemporary world as providing a choice of the best ways to reform and reorganise police institutions in failed states or states emerging from international or civil wars. ${ }^{3}$ Yet there was never any serious theorising about these contrasting models during the nineteenth century, rather colonial administrators appear to have made assumptions that something on London Metropolitan lines might pass muster for some towns, but for vast expanses of sparsely populated countryside, they needed some sort of para-military policing and hence they looked to Ireland. In the early 1850s, for example, administrators in the

\footnotetext{
Blanchard, Deluermoz, Glasman (2011, p. 39).
}

3 Emsley (2012); Sinclair (2012). Interviews conducted as part of 'Exploring UK policing practices as a blueprint for police reform: the overseas deployment of UK Police Officers 1989-2009', ESRC Grant RES-000-22-3922, demonstrated the continuing belief in the two models : 'I've reconciled my thoughts to two styles of policing ... the RUC [Royal Ulster Constabulary] was military in style...' [Sergeant, Police Service Northern Ireland, served in Kosovo, Bosnia, Iraq]. 'We're a community orientated police force ... our basic premise is the uniformed officer on the streets.... We're unique ... in that we're unarmed.' [Ex-Metropolitan Police Superintendent with wide ranging international experience including Bosnia and Kosovo]. They also saw themselves as very different from European police who they saw as regimented and state-directed. 
Australian colony of Victoria asked London for 50 men from the Irish Constabulary; but, in the event, they were happy to receive 50 men from London's Metropolitan Police. ${ }^{4}$ Yet on the ground nineteenth-century British colonial administrators were prepared to pick and mix what appeared to suit them best and what was affordable and practical in the circumstances. Admittedly in 1907 it became a requirement that all men destined to command British Imperial Police forces - excepting those of the White Dominions - should undergo training at the Royal Irish Constabulary (RIC) headquarters at Phoenix Park in Dublin. ${ }^{5}$ Arguably this was justifiable by the RIC's primacy among British imperial police forces. But where else might young men have been trained for such a role? There was, after all, no officer corps training for the police in England, Wales and Scotland, while the Phoenix Park Depot dated back to 1842 and, from the outset, had trained RIC officers as well as men. ${ }^{6}$

The model of the English/British police officer - no more than a civilian in uniform, policing by consent, unarmed and non-political - found its classic, if implicit representation in the work of Charles Reith. Reith never took his research beyond the mid-nineteenth century, which meant that he could situate his representation of the Bobby in what appeared to him, and to many others, as a society based on consensus rather than conflict. ${ }^{7}$ Moreover, while he began to produce his books during the interwar period when there were scandals about police corruption, concerns about police brutality and political partiality, and growing numbers of confrontations between police officers and middle-class motorists, the books also appeared to a backdrop of the two world wars. In contrast to his 'British police' Reith set up a European model of 'Gendarmerie-style' policing which was top-down 'ruler-appointed' and essentially 'despotic' even 'totalitarian. ${ }^{8}$ Reith appears not fully to have understood the complexities of the European gendarmeries; nor does he appear to have understood the similarities between European police systems, including those in Britain, during the nineteenth century. In terms of accountability, control and form I have earlier delineated these similarities as being of three types as follows:

1. State military : the Gendarmerie forces, equipped like soldiers and responsible to a section of central government, often a ministry of war.

2. State civilian: generally police forces in capital cities usually, like the gendarmeries, responsible to part of central government, in other words a ministry of the interior and/or of justice. It is important to remember that, until 2000, London's Metropolitan Police had no local government direction and were responsible to the home secretary

3. Municipal: primarily responsible to local government and often only in an attenuated fashion to central government. 'Municipal' is used here in a very

$4 \quad$ Haldane (1995, pp. 20-36).

5 For the scale of this training and some figures of the numbers of Irish officers who served elsewhere in the Empire see Sinclair (2006, pp.16-19). The White Dominions were self-governing by this time.

6 Malcolm, (2006, pp. 86-92).

7 See, for example, Reith (1938) and (1943). Reith referred to the 'British' Police. At the time that he was writing there were around 160 separate forces in England and Wales, others in Scotland and the Royal Ulster Constabulary in Northern Ireland. In addition, virtually all of Reith's examples and his overall history focus on the Metropolitan Police of London. For a Scottish critique see Barrie (2010).

8 Reith, (1952, pp. 20 \& 244). 
broad sense to cover local police attached to a predominantly rural local administration (such as an English county) as well as a clearly urban one. ${ }^{9}$

David Barrie has cogently argued that this typology would be better applied 'if it were broadened out beyond the institutional confines of accountability, organization and finance to incorporate legal, cultural, functional and intellectual structures and influences' ${ }^{10}$ I would not disagree with this since one of the central tasks of the historian is to identify general patterns and changes over time, the contrasts within these patterns, and the reasons for those contrasts. But the issues that Barrie wishes to incorporate, I would suggest, are precisely those that define national and regional differences within the types. Moreover, my original aim was to draw attention to similarities which so easily get ignored in the usual historical focus on a single country or region.

In addition to his failure to understand the situation on continental Europe, there is another significant gap in Reith's work: his omission of Ireland. It would be possible to nit-pick his work by pointing out that the whole of Ireland was united with England, Scotland and Wales during the period that constituted the focus of his work. But while there was a 'state civilian' force for Dublin and, until the late 1860s, 'municipal' police in Belfast and Derry, most of Ireland was policed by the Irish (from 1867 'Royal Irish') Constabulary. This body was armed and deployed along the lines of a gendarmerie, though the British Parliament preferred the term 'constabulary' when pressing forward with the legislation that created it in the early 1820s. ${ }^{11}$ In omitting the Royal Irish Constabulary, however, Reith was following, as well as perpetuating and strengthening, a tradition that understood this body as being quite different from the police deployed in the metropole.

The notion of distinct English and Irish models of policing was cemented in the history of British colonial police published in 1952 by Sir Charles Jeffries, who served as the Deputy Under-Secretary of State for Colonies for ten years from 1946. Jeffries recognised that some form of policing existed before the creation of London's Metropolitan Police, but like the traditional British police historians of his day, he continued to see first, modern policing dating from 1829, and second, the Metropolitan Police as the model. In the colonies, however, he believed that an alternative system was required; and he delineated three phases in the colonial police tradition, with much overlapping and variations in tempo. In the initial phase the basic essentials of law and order had to be secured. Once this was achieved the second phase could be implemented of establishing semi-military constabulary forces that could be called upon to suppress crime and 'mass-outbreaks'. For this purpose Jeffries saw the colonial authorities looking to the RIC for a model.

Into the merits or demerits of this system, as applied to Ireland, it is not for me to enter; but it is clear enough that from the point of view of the

$9 \quad$ Emsley (1999b).

10 Barrie (2010, p. 274). Barrie develops this criticism to challenge the notion of 'British Police'; and while he accepts that there was a greater similarity between police in England and Scotland than some would admit, by addressing his broader issues he is able to expose some marked contrasts 'beyond institutional confines' as a result of cultural, intellectual and legal structures and influences.

11 Palmer (1988, p. 242). 
Colonies there was much attraction in an arrangement that we should now call a 'para-military' organisation or gendarmerie, armed, and trained to operate as an agent of the central government in a country where the population was predominantly rural, communications were poor, social conditions were largely primitive, and the recourse to violence by members of the public who were 'agin [sic] the government' was not infrequent. ${ }^{12}$

During Jeffries's third phase the semi-military constabularies were converted into a form resembling the "essentials [of] the British pattern ... but still retaining certain continuing supplementary functions of a military character.' Also, during this stage, there was the potential for a significant increase in officers and NCOs from the indigenous population. ${ }^{13}$

Jeffries's phases of colonial policing offer a pleasing image of progress and a simple, rational theory of administrative development, yet his description covers neither the complexities that the British found when they first established themselves in the different territories that became their empire, nor those that developed subsequently. There were territories that were vast and undeveloped with scatterings of often nomadic, indigenous peoples; but these peoples had chiefs and elders, arbitration and enforcement traditions, and social norms. Elsewhere there were already significant bureaucratic structures and municipal administrations that included policing systems. However, in what became the United States, and in the kind of territories that the British termed 'White Dominions', cities and towns grew up which often had few indigenous people making a home in them, but which acquired municipal structures, including urban police, very similar to those of the original mother country. The term 'settler colonialism' has been deployed to characterise areas where the settlers became the majority and denied any responsibility for colonialism. ${ }^{14}$ The White Dominions, as well as the USA and many of the states that emerged out of Spanish America, all more or less fit this form of colonialism and, as a result, their police institutions scarcely fit Jeffries's phases of rational development.

\section{DIFFERENT POLICE FOR DIFFERENT SITUATIONS}

The distinction described by Michael Broers with reference to Napoleon's empire is equally useful for illuminating the complexities of European overseas empires during the eighteenth and nineteenth centuries. Broers described an inner core, intermediate zones and an outer empire. ${ }^{15}$ In the British Empire an inner core could be found in the cities, towns and economically developed districts of the White Dominions where, although the European colonists could be troublesome, it was possible to deploy administrative and governmental systems not greatly removed from those in the metropole. The outer fringes, where the indigenous peoples were not particularly wedded to, or indeed much aware of their colonial masters, and

\footnotetext{
12 Jeffries (1952, p. 31).

13 Jeffries (1952, p. 33).

14 Veracini (2010).

15 Broers (1996, especially chapter 5).
} 
where borders were indistinct and porous, required either a laissez-faire attitude or something forceful and vigorous, perhaps even a combination of the two depending on the circumstances. Policing in the European empires was much more pragmatic than Jeffries' formulation; it depended on the structure of the colony, the region to be policed, the finance available and the inter-relationship between those to be policed and the colonial government.

Nearly a quarter of a century ago Richard Hawkins warned that 'anyone who surveys the police forces of the [British] empire, at whatever period, expecting to find so many replicas of the Irish constabulary, will be disappointed and indeed bewildered.' ${ }^{16}$ Sixty years earlier J.C. Curry, a European officer of the Indian Police, could write a book surveying the Indian Police and its history with only one mention of the RIC; specifically a reference to General Sir Charles Napier who, after his conquest of Sind in 1843, created a police for the province on the Irish model. ${ }^{17} \mathrm{~S} . \mathrm{T}$. Hollins, who had grown up in Ireland and who joined the Indian Police in 1902 as a probationary Assistant Superintendent, made no mention of the RIC in his memoir of 44-years-service. Hollins took an examination for the Indian Police in London, and attended a police training college at Moradabad in India alongside two other young British officers and about 120 Indian cadets. ${ }^{18} \mathrm{~A}$ few have tried to explain what was distinctive about the RIC model and the memoirs of former members suggest a strong esprit de corps within the force. Yet the memoirs can be slightly contradictory. Thomas Fennell, who finished his career as a head constable, believed the RIC's spirit to be unique. He also felt it was distinctive from other British police because it was 'a semi-military body drilled and trained to the use of arms on military lines. ${ }^{19}$ Robert Curtis, who was a County Inspector, quoted at length the force's Inspector General who, during the 1860s, challenged criticism of the corps as being 'too military', insisted that there was 'no military mania' and asserted that his men were 'of a different stamp from those in the army'.$^{20}$

Implicitly the difference between the Irish and English police models is that the former had the potential to be more repressive and punitive, or, as Georgina Sinclair has put it, the Irish was "colonial" and armed', the English was "civil" and unarmed.' But as she also notes, the 'civil and colonial models of policing crossfertilized throughout the nineteenth century. ${ }^{21}$ During the 1840 s, for example, a few English counties believed that the Irish Constabulary constituted a better model than the police of London for their own circumstances, and throughout both the nineteenth and twentieth centuries Irish officers were selected to command English police forces. $^{22}$ The RIC was deployed, like most European gendarmeries, in small barracks situated on main roads and containing around half-a-dozen men. The men themselves were almost all native Irishmen, mostly the sons, especially the younger sons of small farmers in the south, west and midlands of the country. No man was permitted to serve in the district of his birth, or that of his wife; and, like the majority

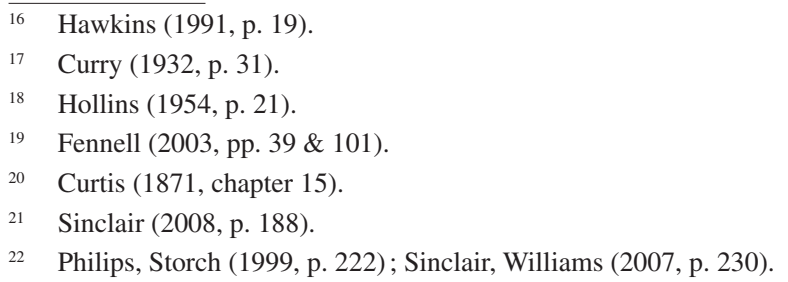


of the population, the men were mainly Catholic. They were armed with rifles and bayonets but, by the turn of the century, they were commonly patrolling without this weaponry and were reasonably well integrated with the local population in which they served. ${ }^{23}$ Indeed, by 1900 the RIC 'Peeler' was not greatly distinguishable from the British 'Bobby' and, possibly for this reason, official thinking on creating the South African Constabulary during the Boer War of 1898-1901 tended to look to the North West Mounted Police of Canada. ${ }^{24}$

The distinction between the English and Irish models continues to be employed at least as a starting point by some of the more recent and perceptive historians of policing in the British Empire; and Sinclair and Williams have argued that colonial police can be categorized, using my typology, as 'state military' forces. Such police, they maintain, evolved as centralised bodies, armed as soldiers and directly accountable to the civil power of a particular colony. ${ }^{25}$ I believe that my earlier typology of nineteenth-century police continues to have relevance for exploring the colonial situation but, as will be discussed in the remainder of this article, in a rather more complex fashion than in Europe. First, in the White Dominions and other areas of settler colonialism, there could be a fusion of state military, state civilian and even municipal aspects within the same force. Second, it is sensible to add a fourth type that might loosely be termed 'colonial franchise policing'. By this term I mean police responsible usually to a local chief in a district where the colonial authority was distant, thin and feeble. ${ }^{26}$ Here leaders of the indigenous communities were authorised to exercise police powers under the suzerainty of the colonial administration. This franchise policing might, depending on the circumstances, be subdivided further as follows:

1. Native: These were policing institutions that existed before colonial occupation but which were authorised to continue under native rulers who had reached an accommodation with the imperial authorities. Generally they functioned within the framework of traditional norms and regulations, and the traditional chiefs or elders maintained their authority over these personnel. They functioned only in districts reserved for this population. Sometimes they were supervised by the colonial power but they rarely had any authority over any Europeans.

2. Restructured: In some instances old police institutions were reorganised by the colonial power; they lost some old powers, gained some new ones, and

23 Griffin (1991); Malcolm (2006). The RIC was forced to return to its para-military style during the Irish War of Independence, and this style was continued by its successor, the Royal Ulster Constabulary, in the expanded province of Ulster after the creation of the Irish Free State in 1922.

24 Grundlingh (1991, p. 169). The South African Constabulary was established during the war and a large number of its men were recruited from Canada and Australia, as well as some Boers who had transferred their allegiance to the British and were known as 'joiners'. 'Peeler' and 'Bobby' have the same origin in the name of Sir Robert Peel who, as Chief Secretary for Ireland established a forerunner of the RIC and, nearly 20 years later as Home Secretary, was responsible for the legislation that established the Metropolitan Police of London.

25 Sinclair and Williams (2007, p. 223). See also Sinclair (2006) for a perceptive use of the Irish model as a starting point.

26 A similar argument is made in Anderson, 1994. Though Anderson suggests that there could be more categories. 
were required to enforce the new forms of law introduced by the imperial authorities.

The edges of these types often shaded into each other, but situations on the ground rarely, if ever, fit the framework of ideal types with precision; and, in the case of police institutions, this is thanks to the kinds of legal, cultural, functional and intellectual structures and influences that David Barrie emphasises.

\section{MISSIONARIES OF (EUROPEAN) CIVILISATION}

In one of the first of the serious, modern analyses of nineteenth-century English policing, Robert Storch described the policeman as a 'domestic missionary', acting as 'an all-purpose lever of urban discipline', as well as dealing with the various other tasks of crime fighting and maintaining public order. ${ }^{27}$ Police in colonial towns and cities had similar roles. But whereas Storch was thinking in terms of establishing a respectable, middle-class morality, in the colonies the police missionary task, at least as far as the indigenous population was concerned, was to impose European values and norms.

The spread of European powers into the wider world was already under way by the late seventeenth century. Two centuries later awareness of the size and shape of the world and rule in the wider world had changed significantly. Much of the difference in the early nineteenth century was the result of colonists liberating themselves from their motherland. Much of the Americas were now governed by former colonists and the focus of European imperialism shifted to Asia, Africa and Australasia. The former American colonists had experience of different police institutions from the old regimes of Europe; in the nineteenth century they began to establish police institutions much on the lines of those being developed in nineteenth-century Europe, though with a recognition of their particular circumstances. The thirteen colonies that came together to form the United States of America brought practices to the Americas similar to those in England, but developed them differently. During the nineteenth century, while sometimes looking to the London Metropolitan Police, city police institutions in the USA were established along the lines of the municipal type but usually with democratic and elective elements. ${ }^{28}$ Police institutions responsible to the governments of individual states were established towards the end of the century for supervising and maintaining order outside of the towns and cities; and a small number of federal police institutions were formed with officers appointed to deal with offences and problems that crossed state boundaries or affected the union as a whole. ${ }^{29}$ The Portuguese imported their quadrilha system to Brazil; this resembled the English system of constables, appointed for a fixed period from dependable local men. Early in the nineteenth century, as the Portuguese royal family fled to its massive South American colony to escape Napoleon's armies, a system of state police was developed along continental European lines. In the early 1830s two state military forces were formalised: the Guardas Municipais Permanentes (in 1831) for

27 Storch (1976, p. 481).

28 Monkkonen (1981).

29 We lack a good comparative study of the development of both State Police and Federal Police in the United States. 
the city of Rio de Janeiro, and the Guarda Policial da Provencia do Rio de Janeiro (in 1835) for the remainder of the province. ${ }^{30}$

Both in the newly independent Americas and in territories that were brought into the expanding nineteenth-century European empires there were white explorers, colonisers, settlers, missionaries and jurists who considered that the indigenous tribal peoples among whom they planted their flags were anarchic, that their laws involved little more than 'revenge', and that they indulged in judicial and penal practises 'only such as are consistent with a state of darkness and irrational superstition' ${ }^{31} \mathrm{In}$ the year that he was instrumental in the creation of the lieutenant général de police de Paris (1667), Jean Baptiste Colbert lamented that so little effort had been made in New France to bring the concepts of police and civil society (la vie civile) to the native Algonkin and Huron peoples. ${ }^{32}$ Others, in contrast, saw aboriginal peoples as having norms and laws that imposed well-considered sanctions on those identified as wrong-doers, and the imposition of sanctions, of course, required some degree of enforcing. ${ }^{33}$ The enforcers of norms in tribal societies came from the community that they served and took their guidance from those, usually chiefs or elders, who held the knowledge of their society's norms. There were, in consequence, tight links and overlaps between any arbitrators or enforcers, their community, and those from whom they took direction. But not all of the territories in which Europeans sought trade and profit, and in which they planted their flags, were populated by nomadic peoples living in relatively small clan-style communities and self-policing according to custom and tradition. There were also much larger polities, particularly in Asia, with significant urban centres and centralised, legalistic forms of government that also experienced varying degrees of European involvement and occupation. By the eighteenth century both Imperial China and Mughal India, for example, had developed policing structures and systems that were in many ways similar to those in Europe. The baojia system, for example, had its origins during the Song Dynasty in the eleventh century and was not unlike the English Frankpledge and the tythings that emerged in the same period. ${ }^{34}$ While in Mughal India policing was seen as a part of the hierarchical structure that ran down from the emperor through his provincial governors and urban administrators. ${ }^{35}$

European imperialists often made little distinction between policing within the small, sometimes nomadic tribes and the structures of sophisticated kingdoms and empires; all of these societies appeared to lack the rationality of European law and administration. The Europeans considered that their systems were best and that they were bringing civilisation even to peoples who had long left small tribal communities; part of this 'civilisation' included the creation and maintenance of what the colonial state defined as 'order' and 'law' and this necessitated the imposition of some form of police institution. Gendarmeries offered one positive way of policing imperial territories and imposing European law. Indeed a key role of the gendarmerie forces (including the RIC) across the nation states and empires

\footnotetext{
30 Holloway (1993, chapters 2 and 3); Leal, Pereira, Filho (2001, chapters 1 and 2).

31 Harring (1994, p. 10); Reynolds (1996, p. 62).

32 Havard (2009).

33 Harring (1994, p. 76); Brown (2002, p. 380).

34 My thanks to Songtao Yang of the University of Henan for information on this point.

35 Sangar (1998, pp. 23-24, 43-45 \& 90-94).
} 
of nineteenth-century Europe, was to show the flag to peasants and emphasise to them that they belonged to a particular nation state or empire. ${ }^{36}$ Yet the vast areas of many colonial territories left gendarmes very thin on the ground. There were rarely more than 1000 members of the French Gendarmerie posted to overseas territories; they were more numerous during military campaigns when the task of policing the army tended to be paramount, but in periods of financial stringency the number of gendarmes overseas could be significantly reduced. ${ }^{37} \mathrm{~A}$ small force of Maréchaussée was established in the Dutch colony of Curaçao in 1838 and, a quarter of a century later, on the eve of slave emancipation, this was extended to Surinam. In total a force of 122 men was recruited from European soldiers based in these Dutch colonies. But a police institution of such numbers was always going to be insufficient to maintain a permanent supervision of the rural areas and the plantations. ${ }^{38}$ In German South West Africa the police was distinct from the army but, while it was required to perform much the same tasks as the soldiers in the territory, there was no notion of describing it as a Gendarmerie. Financial cutbacks reduced the number of 750 men proposed in 1907 to barely 450 six years later. They were expected to police only about 60 per cent of the colony and rode through their respective districts to remind the indigenous population (estimated at the time to be about 60,000) of the presence of German soldiers (about 1900 of them in 1913), and to protect German farmers and other settlers (about 14,000). Like most European empires the Germans appear to have had mixed ideas about precisely what they were doing in South West Africa; the police were supposed to bring and maintain the order necessary for a state on European lines but, like similar colonial police institutions, they were few and thinly spread, and since negotiation was usually better than force in day-to-day dealings with the indigenous peoples, the German policemen were also seriously hampered by their lack of knowledge of the native languages. ${ }^{39}$

From the revolution of 1848 successive French governments considered Algeria to be a part of Metropolitan France; the hope was that it would provide a home for French workers and peasants, but the aspiration was never achieved, not least because of the resistance of the indigenous peoples who were more numerous and, arguably at least, better organised than most of the indigenous peoples of what became Britain's White Dominions. The French swept away the old, apparently relatively effective policing structure and replaced it with their state-civilian commissaires de police for the cities and big towns and their gendarmes for the fringes of the towns and the main routes. A posting to Algeria was rarely popular with gendarmes from the metropole. The harshness of the terrain and the dangers of disease, the difficulties of supply and the unpleasant nature of distant territory for a man separated from, or even accompanied by, his family, all counted against it - though it has to be admitted that the harshness of Algeria was probably matched in the eyes of many men by the problems in Corsica where an alien, often hostile population, with out-dated ideas of honour and violence, combined with a harsh terrain and a high incidence of malaria to make this a similarly undesirable posting. ${ }^{40}$

\footnotetext{
Emsley (1999a).

37 Besson and Rosiere (1982, pp. 196 \& 233).

38 Klinkers (2012, pp. 50-51).

39 Zollmann (2011).

$40 \quad$ Lorcy (2011); Fieschi (2012).
} 
Algeria, however, was vast and way beyond the supervision of the thousand or so gendarmes that composed the police garrison beyond the towns. One solution was to recruit members of the indigenous community as auxiliaries for the gendarmerie. French Algeria was not the only overseas possession to employ such auxiliaries. In German South West Africa black African Polizeidiener (police servants) were considered indispensable and were entrusted with their own armed patrols without a supervising white man. ${ }^{41}$ Nevertheless up until the end of the First World War most auxiliary corps generally had white, European officers; and, even after 1919, white officers appear to have predominated in the senior posts of most such units. Within their institutional confines most of these forces still fit broadly into the state/military form of police; indeed, in some instances they were military or militia bodies given new titles and badges - the transfer of 10,000 or so Kikuyu Home Guard into the Tribal Police of Kenya in 1956 is a classic example. ${ }^{42}$

It was not just 'auxiliaries' that had European officers. Most colonial, as opposed to local native, police forces in British Africa had British officers, sometimes with a few junior Asian officers, and a rank and file made up entirely of Africans. ${ }^{43}$ It was much the same in India where, in 1861, the police stationed in the Madras Presidency had 64 Europeans, 93 Anglo-Indians and 24,033 Indians. At the same time, in Calcutta the police numbered 106 European and 2,993 Indians, but few of the latter were natives of Calcutta. ${ }^{44}$ The British tended to divide the Indian races. They considered that Bengalis were physically inferior and were inclined towards intellectual pursuits, consequently for policemen, as for soldiers, they put their faith in men from those that they considered to be of the 'martial races' - mainly Muslims from the north of the subcontinent. ${ }^{45}$ Elsewhere in the empire such martial races were sometimes preferred to recruits from the indigenous population. Throughout their colonial management of Hong Kong, the British found many of their police recruits for the island among the martial races of the Indian subcontinent. At the end of the First World War they also recruited big, tough men from Shandong province; the problem was that while these men were ethnic Chinese and had a hefty physical presence, they had a poor grasp of Cantonese, the language of the majority of Hong Kong Chinese, and little or no English. ${ }^{46}$

Just because some imperial police institutions were called 'gendarmeries', 'constabularies' or even 'police' forces, however, it was not necessarily the case

41 Zollmann (2011, pp. 40-41).

42 This is something that continues in post-colonial states. In Uganda, for example, demobilised soldiers have been transferred directly into the Police or the Police Reserve. My thanks to David Anderson for this information.

43 Anderson (1991, p. 184).

44 Arnold (1986, p. 43); Robb (1991, p. 128).

45 Arnold (1986, pp. 40-42).

Curry, 1932, the former British Police Officer in India, provides some interesting perspectives on this. For example: 'The Hindus of Bengal have no fighting traditions, which is one of the psychological reasons for terrorism and assassination as a political weapon being adopted by certain small groups among them' (p. 40); 'There are tribal communities like the Sindhis who will at times turn out to attack robbers ... but apparently do not make efficient fighting troops.... There are again others like the Bhils, aborigines not yet definitely out of the hunting stage of human development, who regard it as something of a joke to form a gang and rob a fat trader or a moneylender ... who have for generations joined the Bhil Corps, as irregulars or police for local service...' (p. 42).

46 Ho, Chu (2012, pp. 16-18 \& 25). 
that they were engaged in tasks that conventionally came under the broad heading of policing in the metropole. Nor did they always resemble the missionary tasks of bringing European civilisation to the indigenous peoples. The first premier of the dominion of Canada, Sir John A. Macdonald, telegraphed London for information about the RIC when he planned an expedition to plant the flag in the newly-acquired western territories between Manitoba and the Rocky Mountains. But, while Macdonald insisted that the men on his expedition be called 'police', the 270 men of the North West Mounted Police (NWMP) that embarked on the Great March West in 1874 wore the scarlet tunics of the British army, rode and were equipped like a regiment of dragoons, and also had the benefit of small artillery pieces. Most of them were native-born, white Canadians; no more than 14 seem to have been born in Ireland. ${ }^{47}$ George Bowen, the first Governor of Queensland, claimed in 1860 that he wanted a native police on the 'Irish model'. However the Native Police established in Queensland - made up of Aboriginal rank and file with European officers - was principally required to remove other Aboriginal people from their land to make way for white settlement. Like other Native Police in Australia, these mounted police troopers behaved more like marauding military auxiliaries, killing their prey, destroying small camps, and burning bodies together with any other evidence of their murderous behaviour. ${ }^{48}$

Even though British colonial governments thought that there might be something significant about the Irish Police, and even though they were often eager to employ former members of the RIC, they were also often sympathetic to the state-civilian model of the Metropolitan Police, particularly for urban areas. In the Madras Presidency during the mid-1850s, in spite of concerns about security and a high level of violent crime, the Irish model was deemed too military. Lord Harris, Governor of Madras, and Sir William Robinson, his police commander, devised a compromise by which the majority of men were unarmed while a small, armed reserve was maintained for each district. Initially it was intended that the membership of the two groups would be interchangeable, but the situation solidified and the two groups developed separate identities. The system established by the Madras Police Act of 1859 became common throughout British India. Both the armed and the unarmed police were responsible to central authority but, given the size of the imperial possessions, it was recognised that an all-India supervision of police was impossible and, in consequence, as with other government business in India, the police were organised within, and answerable to, the British provincial administrations. ${ }^{49}$

In India, as elsewhere where the indigenous people were seen as requiring European tutelage, there was no consultation about police reform and reorganisation. But nor was there much consultation when it came to policing towns full of white immigrants, or the sons and daughters of immigrants (or, in the case of New South Wales and Tasmania, convicts). In these situations, however, colonial administrators were often inclined to look to London's Metropolitan Police for their model. The population of early nineteenth-century Sydney, for example, had brought from Britain a distrust of state-controlled police such as the French Gendarmerie; but, in spite of their fears of convicts, of freed convicts, aboriginals and bushrangers, they

\footnotetext{
47 Horrall (1972); MacLeod (1976, chapter 6).

48 Richards (2008).

49 Arnold (1986, pp. 27-28).
} 
preferred a system based on that of London. In 1841 they received from England as their First Police Magistrate and Chief Police Officer, William Augustus Miles, a man who had served as an Assistant Commissioner on the Royal Commission on a Rural Constabulary, who shared the ideas on police proposed by the great moral entrepreneur Edwin Chadwick, and who was determined to introduce the London system to the antipodes lock, stock and barrel. ${ }^{50}$ The city of Melbourne, in the neighbouring colony of Victoria, might have recruited large numbers of Irishmen into its police but, during 1850s and subsequently, the colonial government was keen to have its urban police following closely the style of beat policing aimed at the prevention of crime for which London was becoming famous. ${ }^{51}$ During the $1850 \mathrm{~s}$ both New South Wales and Victoria united their different and independent town police, water police, gold fields police and rural constabularies into single police forces whose members both walked urban beats along Metropolitan Police lines, and patrolled rural districts from small isolated posts. These police were an amalgam of state-civilian and state-military being answerable to the central government of each respective colony; shortly afterwards Queensland and Western Australia did the same. The colony of Tasmania, however, moved in the opposite direction until the end of the century. There had been a centralised police in Tasmania since the 1820 s, when the colony was populated by large numbers of convicts. This force became notorious for infringing liberties, providing little protection, and costing the colonial coffers a considerable amount. By the 1850 s the indigenous population was virtually wiped out, the threats from convicts and bushrangers were seen as things of the past, the colony's government wanted to cut expenditure, and the emerging rural elite wanted to exert its own local authority. Under the Rural Municipalities Act of 1858,50 ratepayers could request the Governor to authorise municipal councils with the power to establish their own policing; and this system continued until the end of the century. ${ }^{52}$

While the 'Mountie' has almost become a symbol for Canada the NWMP, subsequently the Royal Canadian Mounted Police (la Gendarmerie Royale du Canada), was always a small element of the police institutions in the country and in the early part of the twentieth century it was only patrolling the wastes of the new western provinces as a result of contracts signed between those provinces and the federal government. Elsewhere in Canada the structure of policing largely followed that of the boroughs of provincial England with the forces responsible, first and foremost to the local state - the city council and, sometimes, police commissioners. These were unquestionably municipal police institutions and different towns and cities selected their recruits according to their own preference - local men or immigrants, the sons of Canadian farmers or tradesmen, Scots, Protestants, and in Quebec, of course, the men needed a working knowledge of French. ${ }^{53}$

In Canada, in spite of the wide-open spaces and the centrality of the Mountie in the country's popular history, policing had begun in the urban districts populated by European colonists. The situation was much the same in Australia where 'it was

\footnotetext{
50 Philips (2001, especially chapter 7).

51 Wilson (2006, especially chapters 1 and 2).

52 Petrow (2005).

53 Marquis (1994).
} 
the city that seemed to harbour the most dangerous criminal frontier' ${ }^{54}$ Special mounted police forces to patrol the rural districts began to appear from the 1830s. These men covered enormous distances on patrols that could take weeks; in 1869, for example, the magistrate in Dalby, just over 100 miles east of the Queensland capital of Brisbane, reported that, over the course of a month, two of his constables had completed a 700-mile patrol executing warrants and delivering summonses. ${ }^{55}$ The development of policing in New Zealand was similar, partly because the first relatively formal police structures were imported from New South Wales. Small urban police bodies designed to deal with white colonists functioned in parallel with an Armed Constabulary established to patrol rural districts and, particularly, to deal with any threat from indigenous Maori.

\section{COLONIAL FRANCHISE POLICING}

It is logical to expect that military and state-civilian police were more significant than municipal variants in colonial settings. The colonial state, after all, generally sought to establish its own mores, legal structures and perceptions of civilization on the often reluctant, indigenous populations. But the vast territories of the nineteenth - and twentieth-century European empires, and the prohibitive costs of providing police officers at levels similar to those of the metropole, meant that professional, bureaucratic police were bound to be thinly spread, particularly outside of the major towns. One remedy, especially in the initial period of colonial domination or in tribal areas only loosely bound to the colonial authority, was what I have called above 'colonial franchise policing'. In this type the colonial power authorized a tribal chief or an indigenous group to carry out policing activity (native police), or to reorganise their activities in ways that introduced and maintained some of the colonists' legal ideas and structures (restructured police).

The East India Company sought to establish itself as the legitimate sovereign power in Madras, Bengal and other territories as they came under its control. But it lacked the resources for a complete reformation of the existing legal systems and so incorporated some traditional institutions into its governing framework. It was from among these institutions, specifically the tahsildars of Madras and the daroghas in Bengal, that it found the men to act as both tax collectors and agents to preserve the peace. These police were drawn from the local society; their office gave them status but, on behalf of their European paymasters, they were expected to maintain new kinds of discipline and order, and to enforce a wider definition of criminal law with rather more rigour than under the Mughals. Since their pay was poor it was hardly surprising that these police persisted in some of the less savoury aspects of policing that had been known under the old order - specifically torturing suspects and taking bribes. Perhaps because of the new rigour at least one Bengal policeman gave receipts for the bribes that he received. ${ }^{56}$ Even after the development of formal police institutions following the Crown's replacement of the East India Company as the colonial power, the watchmen in Indian villages were not formally incorporated

\footnotetext{
$54 \quad$ Sturma (1987, p. 16).

55 Finnane (1991, p. 34).

56 Peers (1991, pp. 30-33).
} 
into the new police even by the 1920 s; they remained local men closely tied to the local elite.$^{57}$ Right up until the independence of India the various Indian princes who acknowledged the British Raj were permitted, amongst their other privileges, to keep their own police. They often borrowed a serving British officer, or appointed one who had retired, to reorganise their police. For example, S.T. Hollins's final appointment, made in 1942, was as the Police Adviser to a dozen such states. Hollins had a poor opinion of the pay and conditions of these police and this, he believed, fostered corruption; but the princes made little response to his assessment. ${ }^{58}$ And the tribal areas of British India's North West Frontier were only ever loosely administered and supervised by the Political Department of the Indian Civil Service (ICS). The Border Military Police was established for the area with a commander drawn from the local Baloch tribes who reported to the local European political officer of the ICS. The Baloch tribesmen who served in the force were given a British Army rifle and a few articles of clothing, but they were expected to provide their own horses. There was little training and little paperwork and, within reason, the Balochs appear to have been permitted to continue their tribal traditions of honour and blood feud. ${ }^{59}$

During the first fifty years of Pakeha ${ }^{60}$ domination in New Zealand there were special judicial arrangements for the indigenous Maori and a Native Constabulary was introduced to control and supervise the indigenous population and to enforce, to some degree, Pakeha norms and prescribed tribal boundaries. George Grey, as Governor of New Zealand in the 1840s, aspired to make the colony's police a mixed force of white men and Maoris. He saw this as a way of projecting European mores and 'civilization' among the indigenous people. Maori police recruited from the sons of tribal chiefs and men of standing, he believed, would go back to their people with European ideas and encourage their acceptance. But there was considerable opposition among the Pakeha to having Maori, especially armed Maori, patrolling streets and exercising any authority over white Europeans. Maori constables were soon limited to dealing with their own kin and tribe, or were also used as occupation forces on other tribes that had proved troublesome to the Pakeha. The Maori considered that service as constables, and their acceptance as such, was a means for them to ensure rangatiralanga, broadly translatable as autonomy; and occupying and policing the lands of tribes who were troublesome to the Pakeha was a means of striking at tribal enemies. By the 1880 s there were plans to phase out the Native Constabulary the colonists considered that Maori behaviour was becoming more acceptable, that the special judicial arrangements were no longer needed and that local people were likely to have too many family links to make useful police in their own communities. At the turn of the century, however, Maori councils were authorised to swear-in their own part-time constables to enforce local laws and regulations. But problems remained as these constables often continued to hold to the traditional ideas of a communal society with distinct customs and laws. As ever, the Pakeha insisted that Maori constables should never interfere with a

57 Robb (1991, pp. 138-140).

58 Hollins (1954, pp. 300-304).

59 Wynne, ed. (1985, p. 73).

60 The etymology of Pakeha, the word commonly used today to denote New Zealanders of European origin, is uncertain. Most probably it comes from the Maori pakehakeha or pakepakeha which was originally used to describe mythical fair-haired and fair-skinned creatures from the sea. 
European unless acting with a white officer. Yet Maori resistance, and the aspirations of rangatiralanga, meant that, even as the Maori became overwhelmingly urbanised in the twentieth century, they continued to exercise their own form of community policing and, towards the end of the twentieth century, the New Zealand government began to recognise the need for some form of partnership rather than simply requiring acceptance of Pakeha systems. ${ }^{61}$

In Nigeria the British authorised the creation of Native Authority Police Forces to enhance the authority of native administrations, particularly in the north and west of the colony, and to ensure their loyalty to British suzerainty. Many of these forces were based on the police systems that had existed before the arrival of the British and, while in their revised forms they were no longer recruited from slaves, they continued after Nigerian independence and until the collapse of the first republic in $1966 .^{62}$ The South African Constabulary were used to deter risings by the indigenous peoples and to assist mine-owners when dealing with industrial disputes but, in general, they did not patrol locations where African tribal chiefs still ruled and remained responsible for law and order. ${ }^{63}$ In the Sudan, during the 1920s, the British established tribal police who acted under the authority of the local chiefs, but who provided a link between the chief and the nearest British District Commissioner. ${ }^{64}$

While it was not an imperial colony in the sense of those territories in Africa and Asia occupied by Europeans during the nineteenth century, there were similar native police developed in one of the greatest areas of settler colonialism, the western United States. The police established under the Bureau of Indian Affairs for the Plains Indians profited from traditions that existed before the white man came. As Dr Valentine McGillycuddy, one of the Bureau's agents, put it:

The Indians generally recognise the police authority, for, from time immemorial, there has existed among the Sioux and other tribes, native soldier organizations, systematically governed by laws and regulations. Some of the strongest opposition encountered in endeavouring to organize the police force ... was from these native organizations, for they at once recognised something in it strongly antagonistic to their ancient customs, namely force at the command of the white man opposed to their own. ${ }^{65}$

Recruits to the Indian police were attracted by the regular job, the pay and the authority that the position offered them. The Bureau's agents were keen to recruit those who had shown themselves hostile to the white man's rule, hoping, in this way, to win over the more dangerous and threatening bands. But men more sympathetic to the white man predominated and the police were often involved in factional squabbles between the traditionalists and the so-called progressives who were more ready to accept the new order of things.

The problems of men being torn between their communities and the people that paid their wages was not something unique to the empires. In parts of Great Britain it was the policy of chief constables to recruit men from outside their force's

\footnotetext{
Hill (1986, pp. 238-239 \& 252); Hill (1995, pp. 65-67\& 127-130); Hill (2005).

62 Rotimi (2001, chapter 1).

63 Grundlingh (1991, pp. 176 \& 179).

64 Johnson (1991, pp. 159-162).

65 Harring (1994, p. 185).
} 
jurisdiction so as to avoid such difficulties and to ensure that men 'maintained the peace and enforced the law' without fear or favour. But in the empires - as well as in parts of Europe where the peasantry spoke a significant patois or a different language from that of the state's bureaucracy - the policy of recruiting strangers to police strangers also created the kinds of problems noted above, for example, with reference to the Shandong men recruited to police Hong Kong. And if there was a problem over recruiting strangers to police strangers, there were also problems over European attitudes to the jurisdiction of indigenous police officers. Pakeha hostility to Maori police constables exercising authority in white men's towns has already been noted. Elsewhere white settlers and businessmen commonly refused to be policed by indigenous peoples and expressed alarm about them being authorised to carry, and trained in the use of, firearms. Such fears were expressed with reference to the Aboriginal police in Australia and elsewhere where the black man was seen as uncivilised and one who easily slipped out of the control of his white officers. ${ }^{66}$ In the early years of the British occupation Chinese police in Hong Kong were not authorised to carry firearms, were not allowed on late night duty, and were not stationed in the European districts. In yet another example of franchise policing Chinese businessmen arranged for, and partially funded a separate night-time watch in their districts; the District Watchmen Forces in the colony were monitored by European inspectors, but supervised also by a board comprising 15 Chinese community leaders under the chairmanship of the Secretary for Chinese Affairs. This was distinct from the management of the Hong Kong Police itself which came directly under the governor's central administration. ${ }^{67}$

Just as there are exceptions to rules, so there are exceptions in administrative models. From the 1920s the Western Townships of Johannesburg appeared increasingly to be centres of violent crime. The aspiring black middle class in the townships worried about poorly-educated young men in low-paid, dead-end jobs and about unruly migrant workers who, together, seemed responsible for the violence. The South African Police (SAP) appeared more interested in enforcing pass-laws and alcohol regulations than in combating crime; as a consequence the adult black community established its own police patrols. When the situation came to a head in the early 1950s the white Johannesburg City Council and its Non-European Affairs Department were sympathetic to the community patrols. Most senior officers of the SAP were hostile; and the central government did nothing. The response from the centre was hardly surprising: the SAP did not want to admit that it could not control the districts; the Apartheid government did not want to suggest any loss of legitimacy which allowing blacks to police themselves might imply. ${ }^{68}$

\section{THE IMPORTANCE OF MODELS AND FRAMEWORKS}

At the beginning of this essay there was a quotation from an article by three young academics engaged in valuable work on colonial policing: it suggested the irrelevance of thinking in terms of the transfer of models. Vincent Denis and

\footnotetext{
66 Richards (2008, pp. 180-181 \& 198-199).

67 Ho, Chu (2012, pp. 13-15).

68 Goodhew (1993).
} 
Catherine Denys have argued that research into models of colonial police tends to obscure rather than illuminate; though they stress that men in the colonies selected from the forms and vocabulary with which they were most familiar. ${ }^{69}$ It may be that, in imagining police, the British have developed a sharper perception of models than their continental European neighbours. Identifying English and Irish models was, from the nineteenth century, a way to draw a distinction between the idealised nonpolitical, unarmed Bobby and his armed, para-military Irish counterpart. At the same time an even sharper distinction could be drawn between the idealised Bobby and an imagined perception of continental European police based largely on ignorance and prejudice.

My own position is that types and models are tools for exploring the past, not things for the historian to pursue slavishly, and not something into which past institutions should be forced and hence distorted. Moreover if historical actors employed models and types in debate and discussion, as they often did, it is important to get to grips with what they understood by these types and models; and all the more so when these models and types continue to be used in contemporary politics and contemporary understandings of the police. The cross fertilization of ideas about institutions, and the use of foreign models in political debate - sometimes distorted to make a political case or point - is nothing new. It was common in Europe with reference to policing during the eighteenth and nineteenth centuries. ${ }^{70}$ British imperial administrators were often vague about the RIC model, but appear to have assumed that it had a military and punitive potential which they might require; some English magistrates during the 1840s appear to have concluded that the nature and deployment of the Irish Constabulary made it more relevant to their rural county than the urban-based London Metropolitan Police. But no self-respecting nineteenth-century Englishman was going to suggest deploying a French gendarmerie-style institution either at home or within the empire, even though in terms of accountability, organisation and finance this was essentially what the Irish force was. Moreover British colonists shared the beliefs of those in the mother country; they disliked the idea of a military or para-military-style police in predominantly white cities and towns and expected to be policed by something similar to the state civilian or municipal models of the metropole. But for the historian models and types should never be more than a starting point, a means of establishing frameworks that can be used to explore similarities and differences, and how different regional, national, imperial circumstances and structures inter-acted with other elements to produce variations in forms and practices. If historians ignore broad types they are restricting their vision, and too much history fails to look beyond national confines.

Clive Emsley

Professor Emeritus

Open University, Walton Hall

Milton Keynes MK6 7AA - UK

Email: c.emsley@open.ac.uk

69 Denis, Denys (2012, p. 11).

70 Emsley (2007, pp. 64-65, 201 \& 206); Johansen (2013). 


\section{BIBLIOGRAPHY}

Anderson, D.M., Policing, prosecution and the law in colonial Kenya, c. 1905-39, in Anderson, D.M., Killingray, D. (eds), Policing the Empire: Government, Authority and Control, 1830-1940, Manchester, Manchester University Press, 1991, pp. 183-200.

Anderson, D.M., Policing the settler state: Kenya 1900-52, in Engels, D., Marks, S. (eds), Contesting the Colonial State: State and Society in Africa and India, London, Academic Press, 1994, pp. 248-266.

Anderson, D.M., Killingray, D. (eds), Policing the Empire: Government, Authority and Control, 1830-1940, Manchester, Manchester University Press, 1991.

Arnold, D., Police Power and Colonial Rule: Madras 1859-1947, Delhi, OUP, 1986.

Barrie, D.G., A Typology of British Police: Locating the Scottish Municipal Police Model in its British Contest, 1800-35, British Journal of Criminology, 2010, 50, pp. 259-277.

Berlière, J.-M., Lévy, R., Histoire des polices en France de l'ancien régime à nos jours, Paris, Nouveau Monde, 2011.

Besson, General J., Rosière, P., La Gendarmerie nationale, Paris, Xavier Richer, 1982.

Blanchard, E., Deluermoz, Q., Glasman, J., La professionnalisation policière en situation coloniale: détour conceptuel et explorations historiographiques, Crime, histoire et sociétés/ Crime, history and societies, 2011, 15, pp. 33-53.

Broers, M., Europe under Napoleon, 1799-1815, London, Arnold, 1996.

Brown, D.H., "They punish murderers, thieves, traitors and sorcerers": Aboriginal criminal justice as reported by early French observers, Histoire sociale/ Social history, 2002, 35, pp. 363-391.

Curry, J.C., The Indian Police, London, Faber and Faber, 1932.

Curtis, R., The History of the Royal Irish Constabulary, $2^{\text {nd }}$ edn. Dublin, McGlashan and Gill, 1871.

Denis, V., Denys, C. (eds), Polices d'Empires XVIII ${ }^{e}$-XIX $X^{e}$ siècles, Rennes, Presses Universitaires de Rennes, 2012.

Emsley, C., Gendarmes and the State in nineteenth-century Europe, Oxford, OUP, 1999a.

Emsley, C., A Typology of Nineteenth-Century Police, Crime, histoire et sociétés/ Crime, history and societies, 1999b, 3, pp. 29-44.

Emsley, C., Crime, Police and Penal Policy: European Experiences, Oxford, OUP, 2007.

Emsley, C., Marketing the Brand: Exporting British Police Models 1829-1950, Policing: A Journal of Policy and Practice, 2012, 6, pp. 43-54.

Fennell, T., The Royal Irish Constabulary, Dublin, University College Dublin, 2003.

Fieschi, S., Les Gendarmes en Corse, 1927-1934: de la création d'une compagnie autonome aux derniers 'bandits d'honneur', Tulle, Service historique de la Défense, 2012.

Finnane, M., The varieties of policing: colonial Queensland, 1860-1900, in Anderson, D.M., Killingray, D. (eds), Policing the Empire: Government, Authority and Control, 18301940, Manchester, Manchester University Press, 1991,, pp. 133-151.

Godfrey, B.S., Dunstall, G. (eds), Crime and Empire 1840-1940 : Criminal justice in local and global context, Cullompton, Willan Publishing, 2005.

Goodhew, D., The People's Police-Force: Communal Policing Initiatives in the Western Areas of Johannesburg, circa 1930-1962, Journal of Southern African Affairs, 1993, 19, pp. 447-470.

Griffin, B.J., The Irish Police, 1836-1914: A Social History, Ph.D thesis, Loyola University of Chicago, 1991.

Grundlingh, A., "Protectors and friends of the people"? The South African Constabulary in the Transvaal and Orange River Colony, 1900-08, in Anderson, D.M., Killingray, D. 
(eds), Policing the Empire: Government, Authority and Control, 1830-1940, Manchester, Manchester University Press, 1991, pp. 168-182.

Haldane, R., The People's Force: A History of the Victoria Police, $2^{\text {nd }}$ edn, Melbourne, Melbourne University Press, 1995.

Harring, S.L., Crow Dog's case: American Indian sovereignty, tribal law, and United States law in the nineteenth century, Cambridge, CUP, 1994.

Havard, G., "Les forcer à devenir Cytoyens". État sauvage et citoyenneté en Nouvelle-France (XVII'-XVIII" siècles), Annales, Histoire, Sciences Sociales, 2009, 64, pp. 985-1018.

Hawkins, R., The "Irish Model" and the empire: a case for reassessment, in Anderson, D.M., Killingray, D. (eds), Policing the Empire: Government, Authority and Control, 18301940, Manchester, Manchester University Press, 1991, pp. 18-32.

Hill, R.S., Policing the Colonial Frontier: The Theory and Practice of Coercive Social and Racial Control in New Zealand, 1787-1867, (Vol. 3 of The History of Policing in New Zealand), Wellington, V.R. Walsh, Government Printer, 1986.

Hill, R.S., The Iron Hand in the Velvet Glove: The Modernisation of Policing in New Zealand, 1886-1917, (Vol. 3 of The History of Policing in New Zealand), Wellington, Dunmore Press, 1995.

Hill, R.S., Maori police personnel and the rangatiratanga discourse, in Godfrey, B.S., Dunstall, G. (eds), Crime and Empire 1840-1940: Criminal justice in local and global context, Cullompton, Willan Publishing, 2005, pp. 174-188.

Ho, L.K.K., Chu, Y.K., Policing Hong Kong, 1842-1969: Insiders'Stories, Hong Kong, City University of Hong Kong, 2012.

Hollins, S.T., No Ten Commandments : Life in the Indian Police, London, Hutchinson, 1954.

Holloway, T.H., Policing Rio de Janeiro: Repression and Resistance in the $19^{\text {th }}$ Century, Stanford Cal., Stanford University Press, 1993.

Horrall, S.W., Sir John A. Macdonald and the Mounted Police Force for the Northwest Territories, Canadian Historical Review, 1972, 53, pp. 179-200.

Jeffries, Sir Charles, The Colonial Police, London, Max Parrish, 1952.

Johansen, A. "Lost in Translation": The English Policeman through a German Monocle, 1848-1914, History, 2013, 98, pp. 750-768.

Johnson, D.H., From military to tribal police: policing the Upper Nile province of the Sudan', in Anderson, D.M., Killingray, D. (eds), Policing the Empire: Government, Authority and Control, 1830-1940, Manchester, Manchester University Press, 1991, pp. 151-167.

Klinkers, E., L'émergence d'une force de police au Suriname: les mutations policières dans une société en mouvement 1863-1900, in Denis, V., Denys, C. (eds), Polices d'Empires XVIII ${ }^{e}$-XIX ${ }^{e}$ siècles, Rennes, Presses Universitaires de Rennes, 2012, pp. 47-61.

Leal, A.B., Pereira, I.B., Filho, O.M., 200 Anos: Polícia Militar do Rio de Janeiro, Rio de Janeiro, Editora PUC Rio, 2001.

Lorcy, D., Sous le régime du Sabre: La gendarmerie en Algérie 1830-1870, Rennes, Presses Universitaires de Rennes, 2011.

MacLeod, R.C., The NWMP and law enforcement, 1873-1905, Toronto, University of Toronto Press, 1976.

Malcolm, E.L., The Irish Policeman, 1822-1922 : A Life, Dublin, Four Courts Press, 2006.

Marquis, G., Power from the Street: The Canadian Municipal Police, in Macleod, R.C., Schneiderman, D. (eds), Police Powers in Canada: The Evolution and Practice of Authority, Toronto, University of Toronto Press, 1994.

Monkkonen, E., Police in Urban America, 1860-1920, Cambridge, CUP, 1981.

Palmer, S.H., Police and Protest in England and Ireland, 1780-1850, Cambridge, CUP, 1988. 
Peers, D.M., Torture, the Police, and the Colonial State in the Madras Presidency, 1816-55, Criminal Justice History, 1991, 12, pp. 29-56.

Petrow, S., The English Model? Policing in late nineteenth-century Tasmania, in Godfrey, B.S., Dunstall, G. (eds), Crime and Empire 1840-1940: Criminal justice in local and global context, Cullompton, Willan Publishing, 2005, pp. 121-134.

Philips, D., Storch, R.S., Policing Provincial England, 1829-1856: The Politics of Reform, Leicester: Leicester University Press, 1999.

Philips, D., William Augustus Miles (1796-1851): Crime, Policing and Moral Entrepreneurship in England and Australia, Melbourne, University of Melbourne, 2001.

Reith, C., The Police Idea, Oxford, OUP, 1938.

Reith, C., British Police and the Democratic Ideal, Oxford, OUP, 1943.

Reith, C., The Blind Eye of History, London, Faber, 1952.

Reynolds, H., Aboriginal sovereignty: Reflections on race, state and nation, St Leonards, NSW, Allen and Unwin, 1996.

Richards, J., The Secret War: A true history of Queensland's native police, St. Lucia, University of Queensland Press, 2008.

Robb, P., The ordering of rural India: the policing of nineteenth-century Bengal and Bihar, in Anderson, D.M., Killingray, D. (eds), Policing the Empire: Government, Authority and Control, 1830-1940, Manchester, Manchester University Press, 1991, pp. 126-150.

Rotimi, K., The Police in a Federal State: The Nigerian Experience, Ibadan, College Press, 2001.

Sangar, S.P., Crime and Punishment in Mughal India, New Delhi, Reliance Publishing House, 1998.

Sinclair, G., At the end of the line: Colonial policing and the imperial endgame, 1945-80, Manchester, Manchester University Press, 2006.

Sinclair, G., The Irish policeman and the Empire: influencing the policing of the British Empire-Commonwealth, Irish Historical Studies, 2008, 142, pp. 173-181.

Sinclair, G., Exporting the UK Police "Brand": The RUC-PSNI and the International Police Agenda, Policing: A Journal of Policy and Practice, 2012, 6, pp. 55-66.

Sinclair, G., Williams, C.A., "Home and Away": The Cross-Fertilisation between "Colonial" and "British" Policing, Journal of Imperial and Commonwealth History, 2007, 35, pp. 221-238.

Storch, R.G., The Policeman as Domestic Missionary: Urban Discipline and Popular Culture in Northern England, 1850-1880, Journal of Social History, 1976, 9, pp. 481-509.

Sturma, M., Policing the Criminal Frontier in mid-nineteenth-century Australia, Britain and America, in Finnane, M. (ed.), Policing in Australia: Historical Perspectives, Kensington NSW, New South Wales University Press, 1987, pp. 15-34.

Veracini, L., Settler Colonialism: A Theoretical Overview, Houndmills Basingstoke, Palgrave Macmillan, 2010.

Wilson, D., The Beat: Policing a Victorian City, Beaconsfield, Victoria, Circa, 2006.

Wynne, M. (ed.), On Honourable Terms: The Memoirs of some Indian Police Officers 19151948, London, British Association for Cemeteries in South Asia, 1985.

Zollmann, J., Communicating Colonial Order: The Police of German South-West-Africa (c.1894-1915), Crime, histoire et sociétés/ Crime, history and societies, 2011, 15, pp. 3357. 